\title{
ランタンを修飾したアルミナ触媒担体の耐熱性と微細構造変化
}

\author{
西尾吉豊·小澤正邦 \\ 名古屋工業大学セラミックス基盤工学研究センター，507-0071 岐阜県多治見市旭ヶ丘 10-6-29
}

\section{Thermal Stability and Microstructural Change of Lanthanum Modified Alumina Catalytic Support}

\author{
Yoshitoyo NISHIO and Masakuni OZAWA \\ Ceramics Research Laboratory, Nagoya Institute of Technology, Asahigaoka, 10-6-29, Tajimi, Gifu 507-0071
}

\begin{abstract}
We investigated the thermal stability and microstructural changes of lanthanum modified $\gamma$-alumina prepared by impregnation process, using aqueous lanthanum (III) nitrate. 0.1-10 mol\% La added aluminas were heated in the temperature range of $600-1400^{\circ} \mathrm{C}$ and characterized by surface area measurement, $X$-ray powder diffraction (XRD), X-ray photoelectron spectroscopy (XPS), differential thermal analysis (DTA), scanning electron microscope (SEM), and transmission electron microscope (TEM). At $1200^{\circ} \mathrm{C}$, the surface area of 0.3 and 1.5 mol\% La modified aluminas were $82 \mathrm{~m}^{2} \mathrm{~g}^{-1}$, while that of pure alumina was $45 \mathrm{~m}^{2} \mathrm{~g}^{-1}$. Even at $1300^{\circ} \mathrm{C}$, the surface area of $5 \mathrm{~mol} \% \mathrm{La}$ modified alumina maintained $24 \mathrm{~m}^{2} / \mathrm{g}$. The solid state reaction of lanthanum oxide with alumina formed $\mathrm{LaAlO}_{3}$ nanoparticles in the secondary particles of alumina. At $1300^{\circ} \mathrm{C}, \mathrm{LaAl}_{11} \mathrm{O}_{18}$ was formed by the reaction of $\mathrm{LaAlO}_{3}$ with $\mathrm{Al}_{2} \mathrm{O}_{3}$.

[Received August 8, 2007; Accepted August 24, 2007]
\end{abstract}

Key-words : Alumina, Lanthanum, Thermal stability, Surface area, Microstructural change

\section{1. 緒 言}

ガンマアルミナ $\left(\gamma-\mathrm{Al}_{2} \mathrm{O}_{3}\right)$ はその高い比表面積と表面特性か ら, 触媒担体として広範囲で使用されている。しかし， $\gamma-\mathrm{Al}_{2} \mathrm{O}_{3}$ は $1000^{\circ} \mathrm{C}$ 以上の高温で $\alpha-\mathrm{Al}_{2} \mathrm{O}_{3} へ$ の相転移を起こし, 大幅な比 表面積低下を起こす．高耐熱性が求められる自動車排ガス浄化 触媒では, 触媒部の温度が $1000^{\circ} \mathrm{C}$ を越えるような使用条件で も, アルミナ担体の熱安定性を持たせることが重要である。 $\gamma$ $\mathrm{Al}_{2} \mathrm{O}_{3}$ の耐熱性向上のため, 元素の添加効果に関して多くの研 究がされている(1)-19). Schaper ら ${ }^{1,2)}$ の報告をはじめとしてその 後の検討により, ランタン $(\mathrm{La})$ を数 $\mathrm{mol} \%$ 添加することによっ て $\gamma-\mathrm{Al}_{2} \mathrm{O}_{3}$ の耐熱性を著しく向上することが知られており，自 動車触媒材料として実用化されるに至っている3) 9),11) 15),18). しかし, La 添加効果や最適化については，その調製法等によっ て添加状態が異なるため様々な報告がある。本研究では含浸法 を用いて $\mathrm{La}$ 添加した $\gamma-\mathrm{Al}_{2} \mathrm{O}_{3}$ を作製し，耐熱性に対して最も効 果的な $\mathrm{La}$ 添加量を調べ微細構造变化を追跡した。 また，SEM およびXPS 測定等を用いて, 微細構造や La の修飾形態を詳し く観察することで, 熱処理に抢ける固相反応と微細構造の変化 とアルミナの耐熱性向上に拈り La の役割について考察した.

\section{1 試料の作製}

\section{2. 実 験}

アルミナ原料として $\gamma-\mathrm{Al}_{2} \mathrm{O}_{3}$ (住友化学工業製，>99.9\%, 110 $\mathrm{m}^{2} / \mathrm{g}$ ) を使用し， $\mathrm{La}$ 添加には含浸法を用い， $\mathrm{Al}_{2} \mathrm{O}_{3}$ の $\mathrm{Al}$ 原子 に対して Laを0.1〜 $10 \mathrm{~mol} \%$ 添加した. 少量の蒸留水に硝酸ラ ンタン $\left(\mathrm{La}\left(\mathrm{NO}_{3}\right)_{3} \cdot 6 \mathrm{H}_{2} \mathrm{O}\right.$; 和光純薬工業製, >95.0\%) を溶解さ せた水溶液を $\gamma-\mathrm{Al}_{2} \mathrm{O}_{3}$ に十分に混合させスラリーとした後に凍 結乾燥し, その後大気中 $600^{\circ} \mathrm{C}$ で 3 時間仮焼した。 さらに大気 中 $800 \sim 1400^{\circ} \mathrm{C}$ の所定の温度で 3 時間の熱処理を行った。

2.2 評価

比表面積測定には $200^{\circ} \mathrm{C} て ゙ 1$ 時間前処理した後の試料につい て, 表面測定装置（柴田科学，SA-1100）を用い77 K に抢ける 窒素ガス吸着により測定した. 試料の相を調べるため X 線回折
装置 (XRD；リガク，RINT-2200）を用い, CuK $\alpha$ 線, $40 \mathrm{kV}, 30$ $\mathrm{mA}$ の条件下, $2 \theta$ を $20 \sim 80^{\circ}$ までの範囲で測定した。熱分析装置 （TG-DTA；マックサイエンス，TG-DTA2000S）を用い，昇温 速度 $5^{\circ} \mathrm{C} / \mathrm{min}$ で $1500^{\circ} \mathrm{C}$ をで昇温し, 相転移の様子等を調べた. 透過型電子顕微鏡（TEM; JEOL, 2000EX）及び走査型電子顕 微鏡（FE-SEM; JEOL, JSM-7000F）によってそれぞれ $160 \mathrm{kV}$ ， $10 \mathrm{kV}$ の加速電圧で粒子の状態を観察した． X 線光電子分光装 置（XPS; JEOL，JAMP-7800）を用い，A12p 及び La3d5 スペ クトルから試料表面組成の評価を行った.

\section{1 比表面積低下の抑制効果}

図 1 に $1000 \sim 1300^{\circ} \mathrm{C}$ で熱処理した試料の La 添加濃度と比表 面積の関係を示す. $1000^{\circ} \mathrm{C}$ 熱処理では $\mathrm{La}$ 添加量の増加にとも ない比表面積が低下した. 無添加試料が $103 \mathrm{~m}^{2} / \mathrm{g}$ であるのに対 して0.1 mol\% $\%$ 添加試料では $96 \mathrm{~m}^{2} / \mathrm{g}, 10 \mathrm{~mol} \% \mathrm{La}$ 添加試料で は $55 \mathrm{~m}^{2} / \mathrm{g}$ まで低下している.これは Laを添加する段階で $\gamma$ $\mathrm{Al}_{2} \mathrm{O}_{3}$ 粒子が凝集したためであると考えられる。しかし, 1200 ${ }^{\circ} \mathrm{C}$ 熱処理では顕著な $\mathrm{La}$ 添加効果が現れた。 $1200^{\circ} \mathrm{C} て ゙ は$ 無添加 試料の比表面積が $46 \mathrm{~m}^{2} / \mathrm{g}$ まで急激に低下したが，わずか 0.1 mol\%の La 添加によりこのような急激な比表面積低下が抑制 され， 0.3 と $1.5 \mathrm{~mol} \% \mathrm{La}$ 添加試料では $82 \mathrm{~m}^{2} / \mathrm{g}$ と高比表面積を 保持した。しかし，さらに La 添加量が増加すると比表面積は 次第に小さくなり $10 \mathrm{~mol} \% \mathrm{La}$ 添加試料では $48 \mathrm{~m}^{2} / \mathrm{g}$ であった. $1300^{\circ} \mathrm{C}$ 熱処理では, 無添加試料の比表面積は $6.4 \mathrm{~m}^{2} / \mathrm{g}$ まで急激 に減少したが， La 添加試料においては $5 \mathrm{~mol} \%$ まで添加量が多 くなるほど比表面積が増加し， $5 \mathrm{~mol} \%$ で $24 \mathrm{~m}^{2} / \mathrm{g}$ を保持した。

\section{2 相変化と固相反応}

DTA 測定ではアルミナの $\alpha$ 相への相転移の様子が発熱ピー

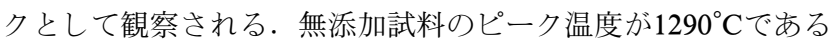
のに対し $1.5 \mathrm{~mol} \% \mathrm{La}$ 添加試料では $1330^{\circ} \mathrm{C}$ と $40^{\circ} \mathrm{C}$ 上昇した。こ のことから図 1 における無添加試料の $1200^{\circ} \mathrm{C}$ での急激な比表面 積低下は $\gamma-\mathrm{Al}_{2} \mathrm{O}_{3}$ の $\alpha$ 転移にともなうものであり, $\mathrm{La}$ 添加はそ 
の $\alpha$ 転移を抑制したため高比表面積を保持したと考えられる.

図 2 に無添加試料 $(0 \mathrm{~mol} \%)$ と $\mathrm{La}$ 添加アルミナ（0.1〜 10 $\operatorname{mol} \%) の 1000^{\circ} \mathrm{C}(\mathrm{a}), 1200^{\circ} \mathrm{C}(\mathrm{b}), 1300^{\circ} \mathrm{C}(\mathrm{c})$ に方ける XRD 回 折図形を示す. $1000^{\circ} \mathrm{C}$ 熱処理において $0.1 \sim 1.5 \mathrm{~mol} \% \mathrm{La}$ 添加試 料では $\mathrm{La}$ を含む化合物はみられなかった. $3 \mathrm{~mol} \%$ 以上の $\mathrm{La}$ 添加試料では $\mathrm{Al}_{2} \mathrm{O}_{3}$ との固相反応によって $\mathrm{LaAlO}_{3}$ 相が生成し

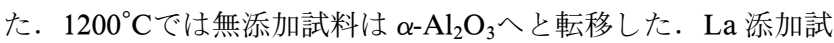
料では $0.1 \mathrm{~mol} \%$ で大幅に $\alpha-\mathrm{Al}_{2} \mathrm{O}_{3}$ 相の回折線が弱くなり, さら に $1.5 \mathrm{~mol} \%$ 以上の添加では $\alpha$ 転移が完全に抑制された。また 0.3 と $1.5 \mathrm{~mol} \%$ 添加試料に打いては, $1000^{\circ} \mathrm{C}$ 同様 $\mathrm{LaAlO}_{3}$ 相が みられず，ランタンはアルミナを修飾していると推察される. $3 \mathrm{~mol} \%$ 以上の添加では $\mathrm{LaAlO}_{3}$ 相の回折線が次第に強くなっ ており，図 1 に示される過剩の La 添加による比表面積低下は $\mathrm{LaAlO}_{3}$ 相の粗大粒子化に起因するものであると考えられる. また層状構造の $\mathrm{LaAl}_{11} \mathrm{O}_{18}$ 相も新たに生成し始めた。 $1300^{\circ} \mathrm{C}$ に抢いては, 低添加量では $\alpha-\mathrm{Al}_{2} \mathrm{O}_{3}$ 相が主相となるが, 添加量 が増加するに従って $\alpha-\mathrm{Al}_{2} \mathrm{O}_{3}$ 相の回折線は次第に弱くなり， $5 \mathrm{~mol} \%$ と $10 \mathrm{~mol} \% \mathrm{La}$ 添加試料では $\alpha-\mathrm{Al}_{2} \mathrm{O}_{3}$ 相は生成していな い. $1.5 \mathrm{~mol} \%$ 以上の $\mathrm{La}$ 添加試料では $\mathrm{LaAlO}_{3}$ 相と $\mathrm{LaAl}_{11} \mathrm{O}_{18}$

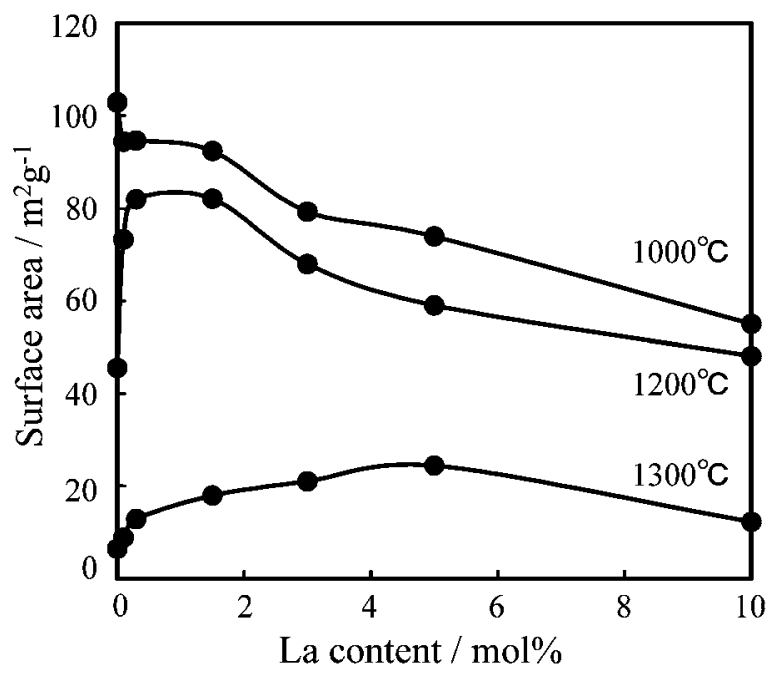

Fig. 1. Specific surface area versus La content for aluminas heated at various temperatures in air for $3 \mathrm{~h}$.
相の回折線強度が $\mathrm{La}$ 添加量の増加にともなって次第に強く

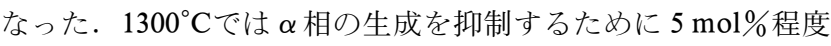
の La 添加が必要となっているが, $10 \mathrm{~mol} \%$ 添加ではこれら 2 種のアルミネート相の粗大粒子が比表面積を低下させてしま うため $5 \mathrm{~mol} \% \mathrm{La}$ 添加試料がもっとも高比表面積となったと考 えられる. 熱処理温度を変化させた一連の試料の XRD 測定か ら, $5 \mathrm{~mol} \% \mathrm{La}$ 添加試料の固相反応は次のような温度領域で進 行することがわかった. $750^{\circ} \mathrm{C}$ 以上から $\mathrm{La}_{2} \mathrm{O}_{3}$ と $\gamma-\mathrm{Al}_{2} \mathrm{O}_{3}$ の固 相反応により $\mathrm{LaAlO}_{3}$ が生成し, $1150^{\circ} \mathrm{C}$ からは固相反応がさら に進行して $\gamma-\mathrm{Al}_{2} \mathrm{O}_{3}$ は $\mathrm{LaAlO}_{3}$ を消費しながら $\mathrm{LaAl}_{11} \mathrm{O}_{18}$ を生 成した。 また $\alpha-\mathrm{Al}_{2} \mathrm{O}_{3}$ は $1350^{\circ} \mathrm{C}$ から生成した。 反応式は以下の とおりである。

$$
\begin{aligned}
& \mathrm{Al}_{2} \mathrm{O}_{3}(\gamma)+\mathrm{La}_{2} \mathrm{O}_{3} \longrightarrow 2 \mathrm{LaAlO}_{3}\left(750 \sim 1150^{\circ} \mathrm{C}\right) \\
& \mathrm{LaAlO}_{3}+5 \mathrm{Al}_{2} \mathrm{O}_{3}(\gamma) \longrightarrow \mathrm{LaAl}_{11} \mathrm{O}_{18}\left(1200^{\circ} \mathrm{C} \sim\right) \\
& \mathrm{Al}_{2} \mathrm{O}_{3}(\gamma) \longrightarrow \mathrm{Al}_{2} \mathrm{O}_{3}(\alpha)\left(1350^{\circ} \mathrm{C} \sim\right)
\end{aligned}
$$

\section{3 固相反応と微細構造}

図 3 に $1000^{\circ} \mathrm{C}$ で熱処理した $5 \mathrm{~mol} \% \mathrm{La}$ 添加試料の $\mathrm{LaAlO}_{3}$ の 生成していない部分の TEM 像を示す。図2で示したように XRD 回折図形からは $\mathrm{La}_{2} \mathrm{O}_{3}$ に相当する回折線は検出されな かった. TEM 像では $\mathrm{La}_{2} \mathrm{O}_{3}$ に相当すると考えられる暗いコン トラストが $\gamma-\mathrm{Al}_{2} \mathrm{O}_{3}$ 粒子を覆うように観察されたが， $\mathrm{La}_{2} \mathrm{O}_{3}$

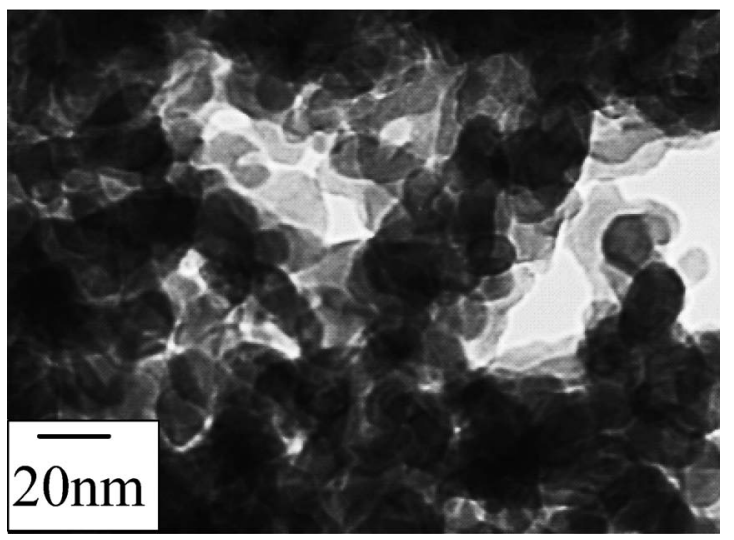

Fig. 3. Transmission electron micrograph of 5 mol\% La-modified alumina heated at $1000^{\circ} \mathrm{C}$ in air for $3 \mathrm{~h}$.
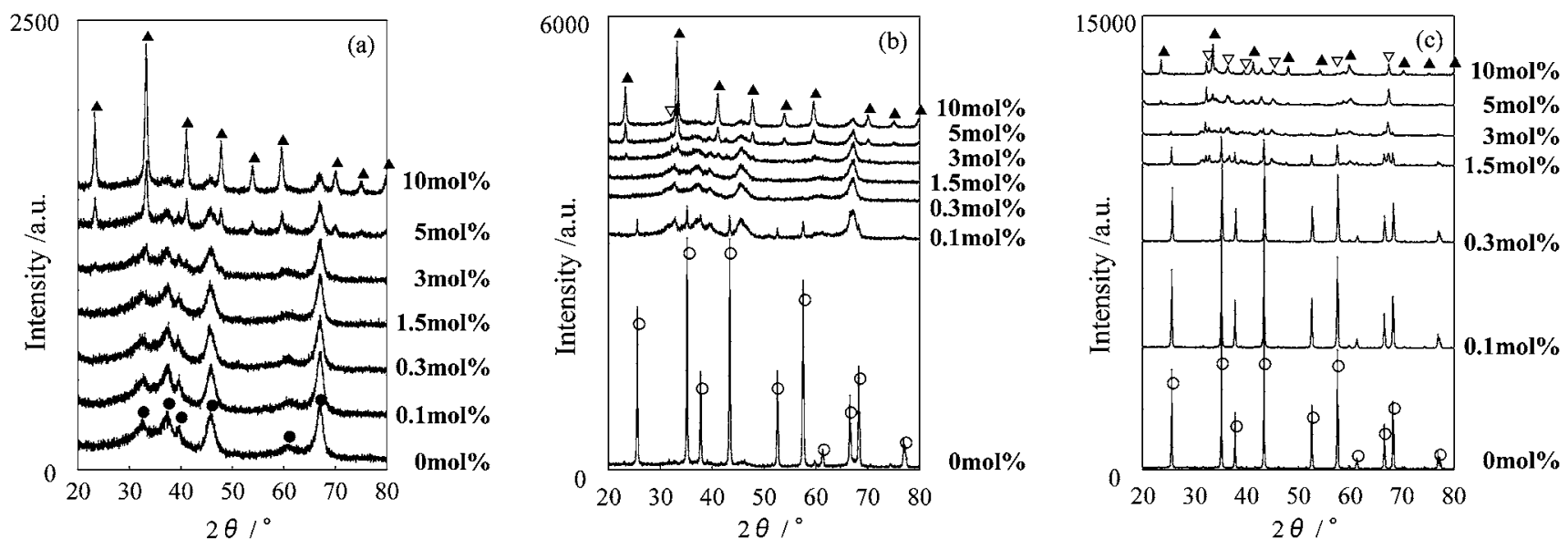

Fig. 2. XRD patterns of La-modified aluminas heated at (a) $1000^{\circ} \mathrm{C}$, (b) $1200^{\circ} \mathrm{C}$, (c) $1300^{\circ} \mathrm{C}$ in air for $3 \mathrm{~h} . \bigcirc \gamma-\mathrm{Al}_{2} \mathrm{O}_{3}, \bigcirc \alpha-\mathrm{Al}_{2} \mathrm{O}_{3}, \boldsymbol{\Delta} \mathrm{LaAlO}_{3}$, $\nabla \mathrm{LaAl}_{11} \mathrm{O}_{18}$. 
Table 1. Surface Composition from XPS, Surfcae Area and Phase for $0.3,1.5$ and 5 mol\% La-Modified Aluminas Heated at $1000^{\circ} \mathrm{Cin}$ Air for $3 \mathrm{~h}$

\begin{tabular}{r|ccc}
\hline La content & $\begin{array}{c}\text { Atomic ratio } \\
\text { La/Al }\end{array}$ & Surface area $/ \mathrm{m}^{2} \mathrm{~g}^{-1}$ & Phases \\
\hline $0.3 \mathrm{~mol} \%$ & 0.008 & 92.0 & $\gamma-\mathrm{Al}_{2} \mathrm{O}_{3}$ \\
$1.5 \mathrm{~mol} \%$ & 0.029 & 92.4 & $\gamma-\mathrm{Al}_{2} \mathrm{O}_{3}$ \\
$5 \mathrm{~mol} \%$ & 0.078 & 73.9 & $\gamma-\mathrm{Al}_{2} \mathrm{O}_{3}, \mathrm{LaAlO}_{3}$ \\
\hline
\end{tabular}

Table 2. Particle Size of $\mathrm{Al}_{2} \mathrm{O}_{3}$ and the Calculated Thickness of $\mathrm{La}_{2} \mathrm{O}_{3}$ layer on $5 \mathrm{~mol} \%$ La-Modified Aluminas

\begin{tabular}{c|ccc}
\hline Temperature & $\begin{array}{c}\text { Particle size of } \\
\text { alumina } / \mathrm{nm}\end{array}$ & $\begin{array}{c}\text { Thickness of } \mathrm{La}_{2} \mathrm{O}_{3} \\
\text { layer } / \mathrm{nm}\end{array}$ & Phases \\
\hline $600^{\circ} \mathrm{C}$ & 27 & 0.38 & $\gamma-\mathrm{Al}_{2} \mathrm{O}_{3}$ \\
$1000^{\circ} \mathrm{C}$ & 30 & 0.41 & $\gamma-\mathrm{Al}_{2} \mathrm{O}_{3}, \mathrm{LaAlO}_{3}$ \\
$1200^{\circ} \mathrm{C}$ & 40 & 0.54 & $\begin{array}{c}\gamma-\mathrm{Al}_{2} \mathrm{O}_{3} \\
\mathrm{LaAlO}_{3}, \mathrm{LaAl}_{11} \mathrm{O}_{18}\end{array}$ \\
\hline
\end{tabular}

（結晶）に相当する電子回折線はみられなかった，添加された $\mathrm{La}$ は非晶質または $\mathrm{Al}_{2} \mathrm{O}_{3}$ 表面に固着した $\mathrm{La}_{2} \mathrm{O}_{3}$ としてアルミ ナを修飾していると考えられる. Burtin ら ${ }^{3)}$ は $\gamma-\mathrm{Al}_{2} \mathrm{O}_{3}$ の 2 つ の表面水酸基の脱水縮合によるアルミナのシンタリング機構を 指摘している. 水酸基は $\gamma-\mathrm{Al}_{2} \mathrm{O}_{3}$ 表面に多量に存在しているが, $\mathrm{La}_{2} \mathrm{O}_{3}$ が $\gamma-\mathrm{Al}_{2} \mathrm{O}_{3}$ の表面を覆っていることでその性質を変化さ せ， $\gamma-\mathrm{Al}_{2} \mathrm{O}_{3}$ のシンタリング及び $\alpha-\mathrm{Al}_{2} \mathrm{O}_{3}$ の核生成を阻害して いるのではないかと考えられる.

表 1 に $1000^{\circ} \mathrm{C}$ で熱処理した $0.3,1.5$ 及び $5 \mathrm{~mol} \% \mathrm{La}$ 添加アル ミナの XPS 測定から求めた粒子表面の $\mathrm{La}$ 組成率, 比表面積括 よび XRD 観察による生成相をまとめて示す，粒子表面の La/ $\mathrm{Al}$ 比は $0.3 \mathrm{~mol} \%$ 添加で $0.008,1.5 \mathrm{~mol} \%$ 添加で $0.029,5 \mathrm{~mol} \%$ 添 加で0.078 となり, 粒子表面での La の偏析を示している.

表 2 に $5 \mathrm{~mol} \% \mathrm{La}$ 添加試料の電子顕微鏡観察から測長した 平均粒径を示した。 また添加した $\mathrm{La}$ がすべて $\gamma-\mathrm{Al}_{2} \mathrm{O}_{3}$ 粒子を $\mathrm{La}_{2} \mathrm{O}_{3}$ として覆ったと仮定して, 平均粒径と $\mathrm{La}$ 添加量から算 出した表面 $\mathrm{La}_{2} \mathrm{O}_{3}$ 層の厚さをその生成相とともに記した. 表面 $\mathrm{La}_{2} \mathrm{O}_{3}$ 層の厚さは $600^{\circ} \mathrm{C}$ で $0.38 \mathrm{~nm}, 1000^{\circ} \mathrm{C}$ で $0.41 \mathrm{~nm}, 1200^{\circ} \mathrm{C}$ で $0.54 \mathrm{~nm}$ であり, $\mathrm{La}_{2} \mathrm{O}_{3}$ の格子定数（六方晶系 $a=0.394 \mathrm{~nm}, c=$ $0.613 \mathrm{~nm}$ ) から表面 1 層を $\mathrm{La}_{2} \mathrm{O}_{3}$ で覆った場合の厚さは $0.394 \mathrm{~nm}$ である. $600^{\circ} \mathrm{C}$ から $1000^{\circ} \mathrm{C}$ に熱処理温度が変化するとき $\mathrm{La}_{2} \mathrm{O}_{3}$ 層が 1 層より大きくなると考えられる. $600^{\circ} \mathrm{C}$ 熱処理試料では $\mathrm{La}_{2} \mathrm{O}_{3}$ は表面に修飾され $\mathrm{LaAlO}_{3}$ 相は生成していないが，表面 1 層の厚みを越えた $1000^{\circ} \mathrm{C}$ 熱処理試料では $\mathrm{LaAlO}_{3}$ 相が生成し ており, さらに $1200^{\circ} \mathrm{C}$ 熱処理試料では表面 1 層の厚みを大きく 越え, $\mathrm{LaAlO}_{3}$ 相抢よび $\mathrm{LaAl}_{11} \mathrm{O}_{18}$ 相が大量に生成している. 以上のことから $\gamma-\mathrm{Al}_{2} \mathrm{O}_{3}$ に添加された $\mathrm{La}$ は, はじめは $\gamma-\mathrm{Al}_{2} \mathrm{O}_{3}$ 表面を 1 層程度で修飾しているが，焼成温度の上昇にともなう $\gamma-\mathrm{Al}_{2} \mathrm{O}_{3}$ の比表面積低下により表面濃度が次第に濃くなってい き, $\gamma-\mathrm{Al}_{2} \mathrm{O}_{3}$ 表面 1 層以上の過剩な $\mathrm{La}_{2} \mathrm{O}_{3}$ が $\gamma-\mathrm{Al}_{2} \mathrm{O}_{3}$ との固相 反応により $\mathrm{LaAlO}_{3}$ を生成するのではないかと推察される. 耐 熱性の向上効果は $\gamma-\mathrm{Al}_{2} \mathrm{O}_{3}$ が $\alpha$ 転移を起こす $1200^{\circ} \mathrm{C}$ 付近の温度
領域で顕著であるが, 実際の使用上 $\alpha$ 転移以前のアルミナの最 適化も必要である。それゆえ, $\mathrm{La}_{2} \mathrm{O}_{3}$ 被覆量は最適化のために 重要である. 本アルミナの場合 $3 \mathrm{~mol} \%$ 以上の La を添加する と表面 $\mathrm{La}_{2} \mathrm{O}_{3}$ 量が過剰になり顕著に $\mathrm{LaAlO}_{3}$ が生成する.

図 4 に $1000^{\circ} \mathrm{C}$ 熱処理，図 5 に $1200^{\circ} \mathrm{C}$ 熱処理した $5 \mathrm{~mol} \% \mathrm{La}$ 添加試料の SEM により撮影した二次電子像とその反射電子像 を示す. $1000^{\circ} \mathrm{C}$ 熱処理試料は XRD 回折図形では $\mathrm{LaAlO}_{3}$ 相が 検出されたが，二次電子像では $\mathrm{LaAlO}_{3}$ に相当する粒子は観察 されなかった。しかし，反射電子像ではアルミナ二次粒子内部 に重元素（La）を含む微粒子が全体的に生成していることが観 察された。二次粒子表面では観察されないことから XRD で検 出された $\mathrm{LaAlO}_{3}$ が $\gamma-\mathrm{Al}_{2} \mathrm{O}_{3}$ の粒子同士の隙間, すなわち $\mathrm{La}$ が多く存在する内部の $\gamma-\mathrm{Al}_{2} \mathrm{O}_{3}$ 表面で核生成したのだと考えら れる. $1200^{\circ} \mathrm{C} て ゙ は ~ \mathrm{LaAlO}_{3}$ 粒子が観察されるのに加え, 板状の $\mathrm{LaAl}_{11} \mathrm{O}_{18}$ がアルミナ二次粒子内部から生成した. $\mathrm{LaAl}_{11} \mathrm{O}_{18}$ は アルミナ二次粒子内部の $\mathrm{LaAlO}_{3}$ と $\mathrm{Al}_{2} \mathrm{O}_{3}$ の固相反応によって 生成するため, アルミナ二次粒子内部から生成している. 熱処 理温度の上昇にともない $\mathrm{LaAl}_{11} \mathrm{O}_{18}, \mathrm{LaAlO}_{3}, \mathrm{Al}_{2} \mathrm{O}_{3}$ は複合組織 を形成した. $\mathrm{LaAlO}_{3}$ は高温で容易に粗大粒子化し,さらなる 固相反応を引き起こしてしまうため, アルミナの比表面積低下 の抑制にもっとも効果的な $\mathrm{La}$ の添加状態は $\gamma-\mathrm{Al}_{2} \mathrm{O}_{3}$ 粒子を覆 う 1 層程度の $\mathrm{La}_{2} \mathrm{O}_{3}$ であるといえる.

\section{4. 結 言}

$\mathrm{La}$ を添加した $\gamma-\mathrm{Al}_{2} \mathrm{O}_{3}$ の耐熱性と微細構造変化について研究 し次の結論を得た。

(1) $\gamma-\mathrm{Al}_{2} \mathrm{O}_{3}$ に La を添加することで高温での比表面積低下 および相転移を抑制することができた。 $1200^{\circ} \mathrm{C}$ 熱処理では 0.3 と $1.5 \mathrm{~mol} \%$ の $\mathrm{La}$ 添加で $82 \mathrm{~m}^{2} / \mathrm{g}, 1300^{\circ} \mathrm{C}$ では $5 \mathrm{~mol} \%$ 添加で 24 $\mathrm{m}^{2} / \mathrm{g}$ という高い比表面積を保持した.

(2) 固相反応は以下のと抢り゙ある. 

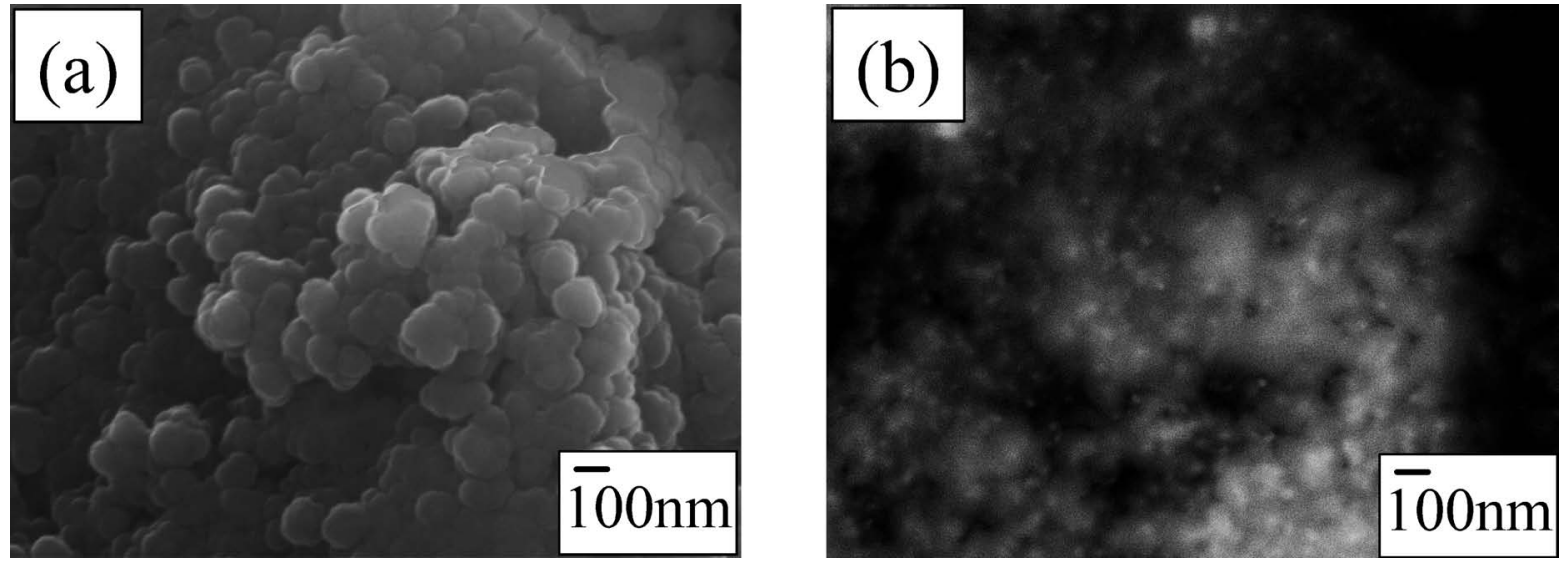

Fig. 4. Scanning electron micrograph of $5 \mathrm{~mol} \%$ La-modified alumina heated at $1000^{\circ} \mathrm{C}$ in air for $3 \mathrm{~h}$. (a) SEM image, (b) REM image.
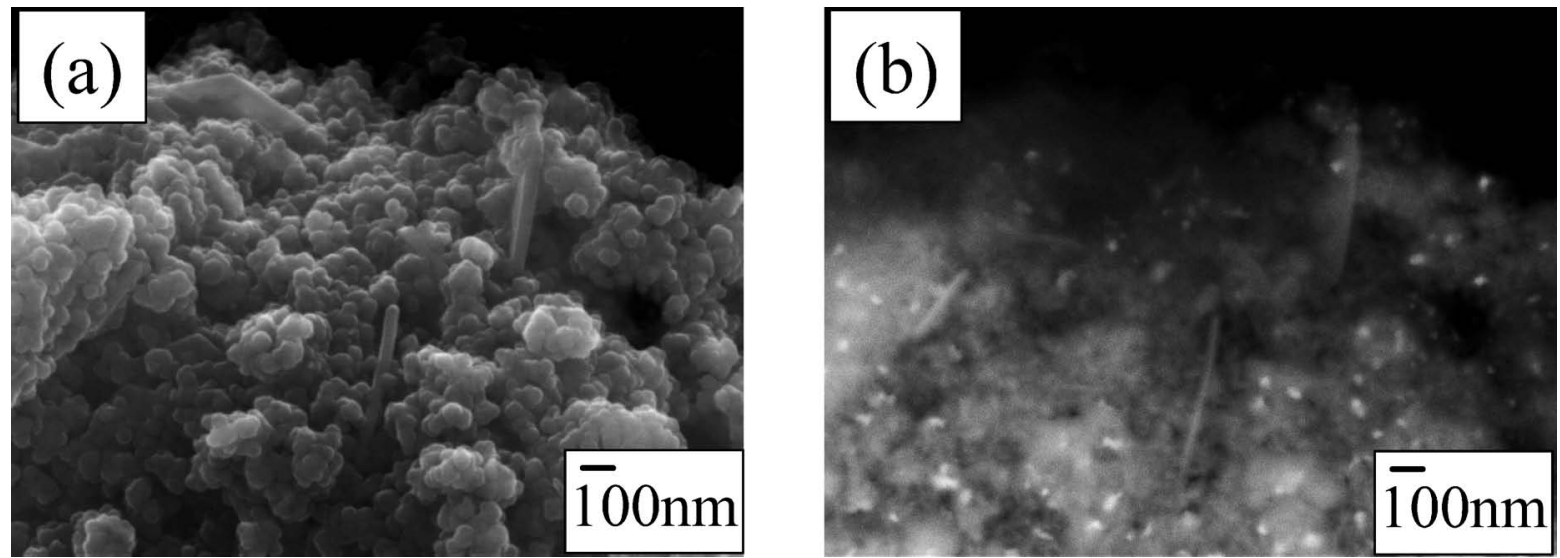

Fig. 5. Scanning electron micrograph of $5 \mathrm{~mol} \%$ La-modified alumina heated at $1200^{\circ} \mathrm{C}$ in air for $3 \mathrm{~h}$. (a) SEM image, (b) REM image.

$$
\begin{aligned}
& \mathrm{Al}_{2} \mathrm{O}_{3}(\gamma)+\mathrm{La}_{2} \mathrm{O}_{3} \longrightarrow 2 \mathrm{LaAlO}_{3} \quad\left(750 \sim 1150^{\circ} \mathrm{C}\right) \\
& \mathrm{LaAlO}_{3}+5 \mathrm{Al}_{2} \mathrm{O}_{3}(\gamma) \longrightarrow \mathrm{LaAl}_{11} \mathrm{O}_{18} \quad\left(1200^{\circ} \mathrm{C} \sim\right) \\
& \mathrm{Al}_{2} \mathrm{O}_{3}(\gamma) \longrightarrow \mathrm{Al}_{2} \mathrm{O}_{3}(\alpha) \quad\left(1350^{\circ} \mathrm{C} \sim\right)
\end{aligned}
$$

(3) $\mathrm{LaAlO}_{3}$ はアルミナ二次粒子内部の粒子間に生成し, $\mathrm{LaAl}_{11} \mathrm{O}_{18}$ も $\mathrm{Al}_{2} \mathrm{O}_{3}$ と $\mathrm{LaAlO}_{3}$ の固相反応によってアルミナ二 次粒子内部から生成する. 添加ランタンははじめアルミナ粒子 表面を修飾しているが, 熱処理による比表面積低下にともなっ て $\gamma-\mathrm{Al}_{2} \mathrm{O}_{3}$ 表面上で過剰となった $\mathrm{La}_{2} \mathrm{O}_{3}$ が反応しアルミネート 相を生成する。

謝 辞 本研究の一部は平成19年度科学研究費補助金, 特定研 究「希土類形態制御」の助成を受けて行いましたことを感謝いたし ます。

\section{References}

1) H. Schaper, E. B. M. Doesburg and L. L. Van Reijen, Appl. Catal., 7, 211-220 (1983).

2) H. Schaper, E. B. M. Doesburg, P. H. M. De Korte and L. Van Reijen, Solid State Ionics, 16, 261-265 (1985).

3) P. Burtin, J. P. Brunelle and M. Soustelle, Appl. Catal., 34, 225-238 (1987).

4) F. Oudet, P. Courtine and A. Vejux, J. Catal., 144, 112-120 (1988).

5) M. Bettman, R. E. Chase, K. Otto and W. H. Weber, J. Catal.,
117, 447-454 (1989)

6) M. Ozawa, M. Kimura and A. Isogai, J. Less-Common Met., 162, 297-308 (1990)

7) M. Kimura, M. Ozawa and A. Isogai, US patent. 4722920 (1988)

8) B. Beguin, E. Garbowski and M. Primet, Appl. Catal., 75, 119-132 (1991).

9) J. S. Church, N. W. Cant and D. L. Trimm, Appl. Catal., A101, 105-116 (1993).

10) M. Ozawa, O. Kato, S. Suzuki, Y. Hattori and M. Yamamura, J. Mater. Sci. Lett., 15, 564-567 (1996).

11) M. Ozawa, H. Toda and S. Suzuki, Appl. Catal., B8, 141-155 (1996).

12) K.-N. P. Kumar, J. Tranto, J. Kumar and J. E. Engell, J. Mater. Sci. Lett., 15, 266-270 (1996).

13) C-K. Loong, J. W. Richardson Jr. and M. Ozawa, J. Alloys Compd., 250 356-359 (1997).

14) M. Ozawa, S. Suzuki and H. Toda, J. Am. Ceram. Soc., 80, 1957-1964 (1997).

15) A. Vásquez, T. López, R. Gómez, Bokhimi. A. Morales and O. Navarro, J. Catal. Solid State Chem., 128, 161-168 (1997).

16) K. Okada, A. Hattori, Y. Kameshima, A. Yasumori and R. N. Das, J. Am. Ceram. Soc., 83, 1233-1236 (2000).

17) K. Okada, A. Hattori, T. Taniguchi, A. Nukui and R. N. Das, J. Am. Ceram. Soc., 83, 928-932 (2000).

18) M. Ozawa and Y. Nishio, J. Alloys Compd., 374, 397-400 (2004).

19) M. Ozawa, J. Alloys Compd., 408-412, 1090-1095 (2006). 